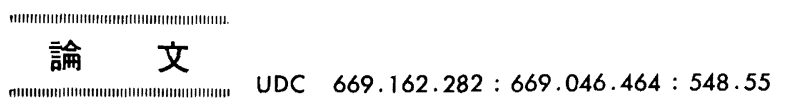

\title{
酸化鉄単結晶の還元試験*
}

\author{
佐山 呴吾** . 植田 芳信** ·横山 慎一**
}

\section{The Reduction of Iron Oxide Single Crystal}

\author{
Sogo Sayama, Yoshinobu Ueda, and Shin-ichi Yokoyama
}

\section{Synopsis:}

The change of crystal structure during the reduction of iron oxide and the growth mechanism of fibrous iron were investigated.

In order to elucidate the crystallographic transition of $\mathrm{Fe}_{2} \mathrm{O}_{3}$ during the reduction, platelets of $\mathrm{Fe}_{2} \mathrm{O}_{3}$ single crystal with flat (0001) plane (approx. $5 \mathrm{~mm}$ in width and $0.5 \mathrm{~mm}$ in thickness) were used as samples. Each of $\mathrm{Fe}_{3} \mathrm{O}_{4}, \mathrm{FeO}$, and $\mathrm{Fe}$ was prepared by the reduction of the $\mathrm{Fe}_{2} \mathrm{O}_{3}$ sample at $750^{\circ} \mathrm{C}$ in the $\mathrm{CO}-\mathrm{CO}_{2}$ mixture with an appropriate composition for each. The structures of the products were analyzed by $\mathrm{X}$-ray diffraction including the Lane methods and scanning electron microscopy (SEM).

The $\mathrm{X}$-ray diffraction revealed that (0001) plane of $\mathrm{Fe}_{2} \mathrm{O}_{3}$ changed to (111) plane of $\mathrm{Fe}_{3} \mathrm{O}_{4}$ and (111) plane of $\mathrm{FeO}$ by epitaxial reactions. SEM revealed that as the reduction proceeded, steps parallel to (0001) plane of $\mathrm{Fe}_{2} \mathrm{O}_{3}$ appeared remarkably, and fibrous iron grew from some nuclei on the steps. The fibrous iron was never seen on (0001) plane of $\mathrm{Fe}_{2} \mathrm{O}_{3}$, and the direction of most active growth was [2 $\overline{1} \overline{1} 0$ ] of $\mathrm{Fe}_{2} \mathrm{O}_{3}$.

\section{1. 緒}

酸化鉄の還元機楧，例えば鉄鉱石の粉化㧍よび異常膨 脤については既に多くの研究がなされている，著者ら1 は前報において 6 種の天然鉱石を試料とし，還元時にお ける異常膨脤の機構について検討した，その結喿鉄鉱石 の結晶構沾と異常膨脤性との間には明らかな関連がある ことを見出した，すなわ台異常膨脹が起きる鉱石は絬㫛 性がよく，かつ微細な規則性（例えげ連品）を示す。一 方異常膨脹を起こさない鉱石は結晶の成長が不卜分で， 不規則なモザイク状組織を示すことが明らかになつた。 しかし天然鉱石は多結晶体てあるために, 絬品面と暹元 特性の関倸についての検討は不十分であつた。

本報に打いては酸化鉄単結品を陚料とし, $\mathrm{Fe}_{2} \mathrm{O}_{3} \rightarrow$ $\mathrm{Fe}_{3} \mathrm{O}_{4} \rightarrow \mathrm{FeO} \rightarrow \mathrm{Fe}$ の各還元過程に打ける結晶配列の変化 をX線回折により，また異常膨脤の原因となる䋐維状金 属鉄の成压機構を走侐電子顕微鏡観察により检讨した。

\section{2. 供試料および実験方法}

\section{$2 \cdot 1$ 供試酸化鉄}

$\mathrm{Fe}_{2} \mathrm{O}_{3}$ 単結晶（板状）, $\mathrm{Fe}_{3} \mathrm{O}_{4}$ 単結晶 (八面体), ブ ラジル赤鉄鉱，スワジーランド赤鉄鈗打上び茂山磁鉄鉱 の 5 種を实験に供した，それら酸化鉄の特徴は次の通り である.

$\mathrm{Fe}_{2} \mathrm{O}_{3}$ 単結晶は知床産で，(0001）面の発達した板状 絬品であり，その大きさは平且面（0001）の幅が約 5 $10 \mathrm{~mm}$ ，厚さは約 $0.5 \mathrm{~mm}$ である。また，へき開面は (0001) および (1011) である (Photo. 1 (a)).

$\mathrm{Fe}_{3} \mathrm{O}_{4}$ 単結品は香烧産で，(111) で国まれた八面体で あり，ての大きさは約 $3 \mathrm{~mm}$ である. Photo. 1 (b)に 八き閒面 (111) を示した.

ブラジル赤鉄鉱は典形的な層状組織を示し (Photo. 1 （c），(0001）面で容易にへき開される.

スワジーランド赤鉄鉱は結晶化が不十分であり，粒界 は不規則なモザイク状を示す（Photo. 1（d)).

茂山磁鉄鉱は，酸化を受けていない緻密な鉱石である

* 昭和 49 年 4 月本会講演大会にて発表

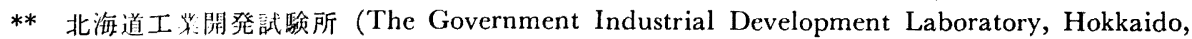
Higashitsukisappu, Toyohira-ku, Sapporo 061-01) 

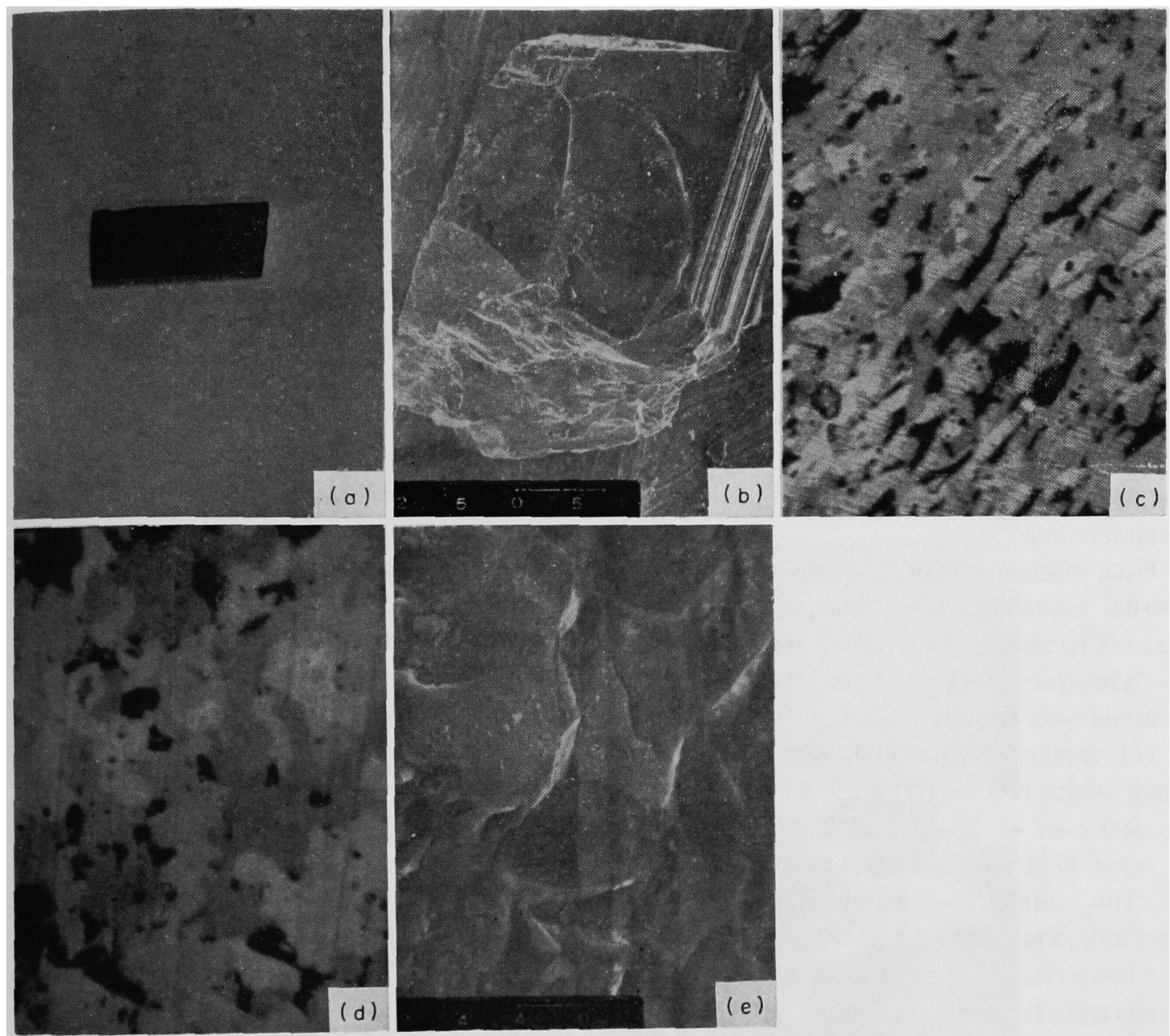

(a) $\mathrm{Fe}_{2} \mathrm{O}_{3}$ single crystal, $\times 1 \cdot 5$, (b) $\mathrm{Fe}_{3} \mathrm{O}_{4}$ single crystal, $\times 25$, (c) Brazil hematite ore, + nicol, $\times 100$, (d) Swaziland hematite ore, +nicol, $\times 400$, (e) Mosan magnetite ore, $\times 250$

Photo, 1. Iron oxide samples.

(Photo. 1 ( e )).

\section{2 実験方法}

走査電子顕微鏡 ( S E M) の試料台 (軟鉄製, 直径 10 $\mathrm{mm}$, 高さ $5 \mathrm{~mm}$ ) 上に酸化鉄試料㓯置き, それを石英 ボートに来せ, 水平管状师（内径 $32 \mathrm{~mm}$ ) を用いて還 元を行なつた.

前報の実験において1，グリーンホールを還元した場 合に最も巽常膨脹が起きるのは約 $750^{\circ} \mathrm{C}$ であつたので 今回の実験においても還元温度は $750^{\circ} \mathrm{C}$ とした. 還元 ガスは CO- $\mathrm{CO}_{2}$ および $\mathrm{H}_{2}-\mathrm{N}_{2}$ で，その流量は $200 \mathrm{cc} /$ min とした. 各酸化状態の酸化鉄は, $\mathrm{CO}-\mathrm{CO}_{2}$ 混合ガ スの組成を変えて還元することにより作られた. 還元後 の試料は電気帓をガスの出口方向に移動させることによ り，反忘管内で放冷を用いない，還元ガスを $\mathrm{N}_{2}$ に切り
変えてから試料をとり出した。試料はSEM 用の試料台 に置かれたままSEM にセットし，還元後の試料表面を 観察した.

$\mathrm{Fe}_{2} \mathrm{O}_{2}$ 板状単結晶は SEM 锶察の他に，X線回折によ る結晶橉造の解析に用いられた。粉末 X線回折装置の試 料台に還元した単結晶を試料台の面に平行になるように 貼りつけ回折を行なつた。 またこの試料は透過ラウエ法 による結晶解析にも用いられた。 ラウエ法はタングステ ン管 $(40 \mathrm{kV}, 15 \mathrm{~mA})$ を用い，試料とフィルム間の距輀 は $40 \mathrm{~mm}$ である.

\section{3. 実 験 結 果}

\section{3 .1 X線回折}

Fig. 1 亿 $\mathrm{Fe}_{2} \mathrm{O}_{3}$ 板状単結晶を $\mathrm{CO}-\mathrm{CO}_{2}$ 気流中で各 


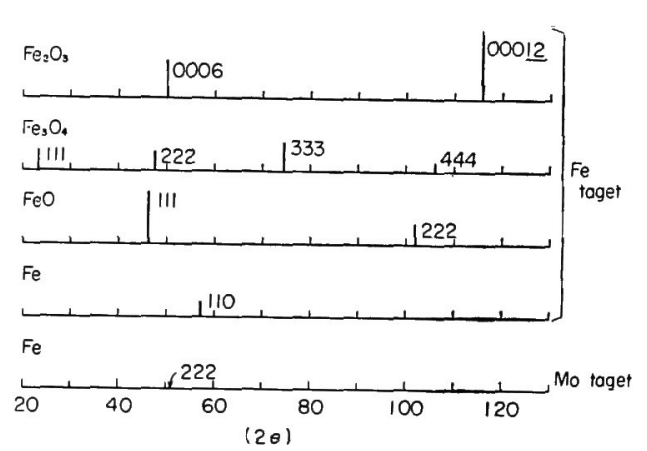

Fig. 1. X-ray difraction lines of reduced product from platelet of $\mathrm{Fe}_{2} \mathrm{O}_{3}$ single crystal.

酸化物の状態まで還元した場合つ，FeF $\boldsymbol{\alpha}$ X線を用いた X線回折の結果を示した.

$\mathrm{Fe}_{2} \mathrm{O}_{3}$ の回折線は (0001) 佂平行な(0006) および (00012)の.が観察された. $\mathrm{Fe}_{3} \mathrm{O}_{4}$ については（111） およびそれ:平行な (222)，(333)，(444) の回折線の みが観察された，FeO については（111）および（222） の回折線のみが倠察された.

以上の結墅より $\mathrm{Fe}_{2} \mathrm{O}_{3}$ の (0001) 面は $\mathrm{Fe}_{3} \mathrm{O}_{4}$ の (111) 面に, さらに $\mathrm{FeO}$ の (111) 面にと還元過程で变化する ことがわかる。

つぎ Fe まで還元された㸝料ついては，極めて弱 い(110)の回折線のみが観察された． Fe (222) の回折

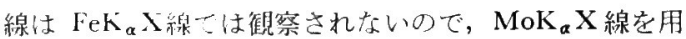
いて回折を行なつた。この結果でも Fe の (222) の回 折線は観察されなかつたので，つぎラウエ法による回 折を行なつた， $\mathrm{H}_{2}$ 気流中で $\mathrm{Fe}$ まで還元された板状試 料の透過ラウエパターン索 Photo. 2 に示した。玫点は かなり乱れておりその面指数を明らかにすることはでき ないか，この結果から還元鉄もおおよそその3 回対称性 を保持して招り，したがつて $\mathrm{Fe}_{2} \mathrm{O}_{3}$ の (0001) 面がそ

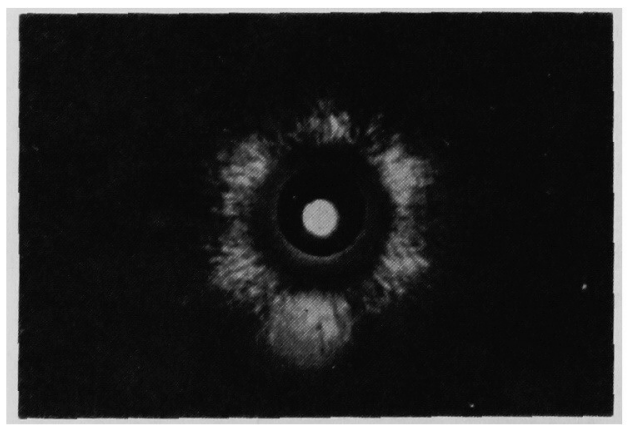

Photo. 2. Raue pattern of iron platelet reduced from $\mathrm{Fe}_{2} \mathrm{O}_{3}$ single crystal, $\times 1$.
の最終還元産物である Fe の (111) 面と一致している 可能性もある.

\section{$3 \cdot 2$ 影微鏡観察}

$3 \cdot 2 \cdot 1 \quad \mathrm{Fe}_{2} \mathrm{O}_{3}$ 板状単結晶の $\mathrm{CO}-\mathrm{CO}_{2}$ 還元

還元前の結晶を Photo. 3 (a) に示した. S EM 写 真上に $\mathrm{Fe}_{2} \mathrm{O}_{3}$ 単結唱の観察した結晶面を次のように印

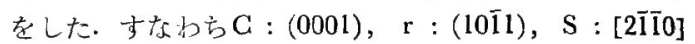
方向が現われる断面である. Photo. 3（b）に拡大した 写真を示した.

Photo. 3 (c) に CO- $\mathrm{CO}_{2}$ 気流中で $\mathrm{Fe}_{3} \mathrm{O}_{4}$ まで培 元した試料の表面を示した. $\mathrm{C}$ 面 $\left(\mathrm{Fe}_{3} \mathrm{O}_{4}\right.$ の (111) 上 には細い亀裂が不規則にみられ， $\mathbf{r}$ 面上には $\mathrm{C}$ 面に平行 なステップが現われる. Photo. 3 (d)に $\mathrm{FeO}$ まで還元 した場合の表面を示した. 大きな龟裂がお抢よそC面に $(\mathrm{FeO})$ (111) に平行に発達するようすがみられる.

Photo. 3 (e) に Fe まで還元された $\mathrm{Fe}_{2} \mathrm{O}_{3}$ 単結晶 を示した.これからわかるように還元前の外形は還元後 もほぼ完全に保たれている. 拡大した写真 Photo.3(f) で示されているように，繊維状金属鉄は $\mathrm{C}$ 面上ではほと んどみられず, 一方その側面上には繊維状金属鉄の成長 は顕著である. Photo. 3（g） は $\mathrm{r}$ 面の拡大写真である が, 繊維状金属鉄のほかに花弁状の突起もみられる.特 に繊維状金属鉄の成長が盛えなのは [21̄10]方向であり (Photo. $3(\mathrm{~h})$ )，それ注 $\mathrm{Fe}_{2} \mathrm{O}_{3}$ の二つのへき開面の交 線のなす方向と一致している.

\section{$3 \cdot 2 \cdot 2 \quad \mathrm{Fe}_{2} \mathrm{O}_{3}$ 板状単結晶の $\mathrm{H}_{2}-\mathrm{N}_{2}$ 還元}

Photo. 3 (i) $\mathrm{H}_{2}$ 気流中で $\mathrm{Fe}$ まで還元した試料 の表面を示した、CO- $\mathrm{CO}_{2}$ 還元の場合とは異なり，C 面と r 面はほぼ同様な組織を示している. Photo. 3(j) にS 面の拡大写真を示したが，還元鉄の表面は滑らかで あり，絽維状金属鉄の成压はみられない.

$\mathrm{H}_{2}$ 還元の場合繊維状金属鉄の成長が 起きるかどうか を確かめるため， $\mathrm{N}_{2}$ で稀釈した $\mathrm{H}_{2}$ ガス $\left(\mathrm{H}_{2}: \mathrm{N}_{2}=20\right.$ :80）を用い還元試験を行なつた。 Fe まで還元された S 面宏 Photo. $3(\mathrm{k})$ に示した. これよりわかるよう に， $\mathrm{H}_{2}$ 濃度の低い気流中で還元を行なつた場合には細 長く金属鉄が成長する傾向がみられる．ただし CO 還 元の場合と比較するとその成長は極めて稳やかである.

\section{$3 \cdot 2 \cdot 3 \mathrm{Fe}_{3} \mathrm{O}_{4}$ 八面体単結晶の $\mathrm{CO}$ 還元}

Photo. 3 (1) に還元前の $\mathrm{Fe}_{3} \mathrm{O}_{4}$ 単結晶を示した. なお $\mathrm{Fe}_{3} \mathrm{O}_{4}$ 単結晶の(111) 面およびそれの破断面をそ

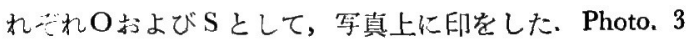
(m) は $\mathrm{FeO}$ まで還元された $\mathrm{S}$ 面を観察したものであ る.

Photo. $3(\mathrm{n})$ に CO 気流中で Fe まで還元した試 


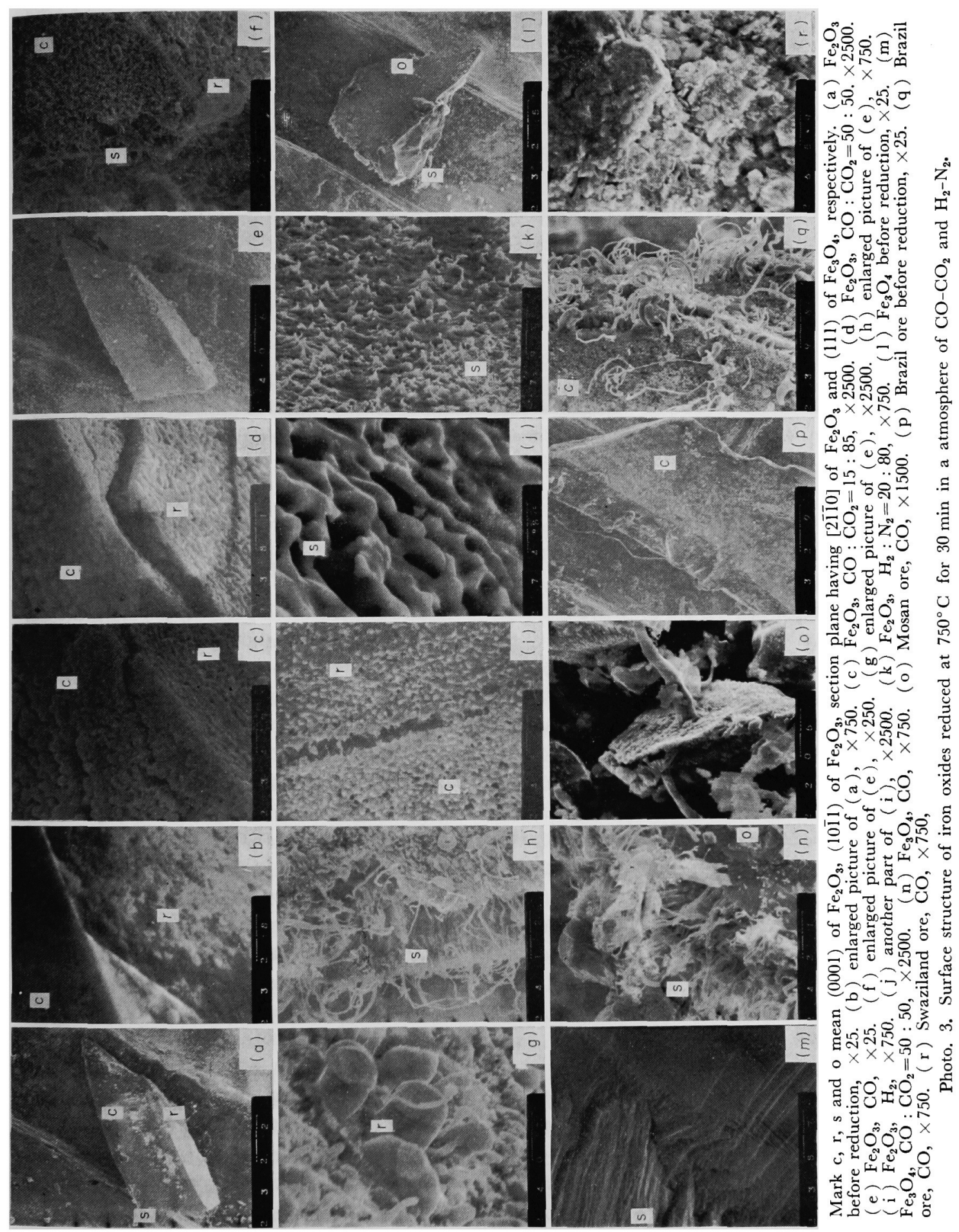



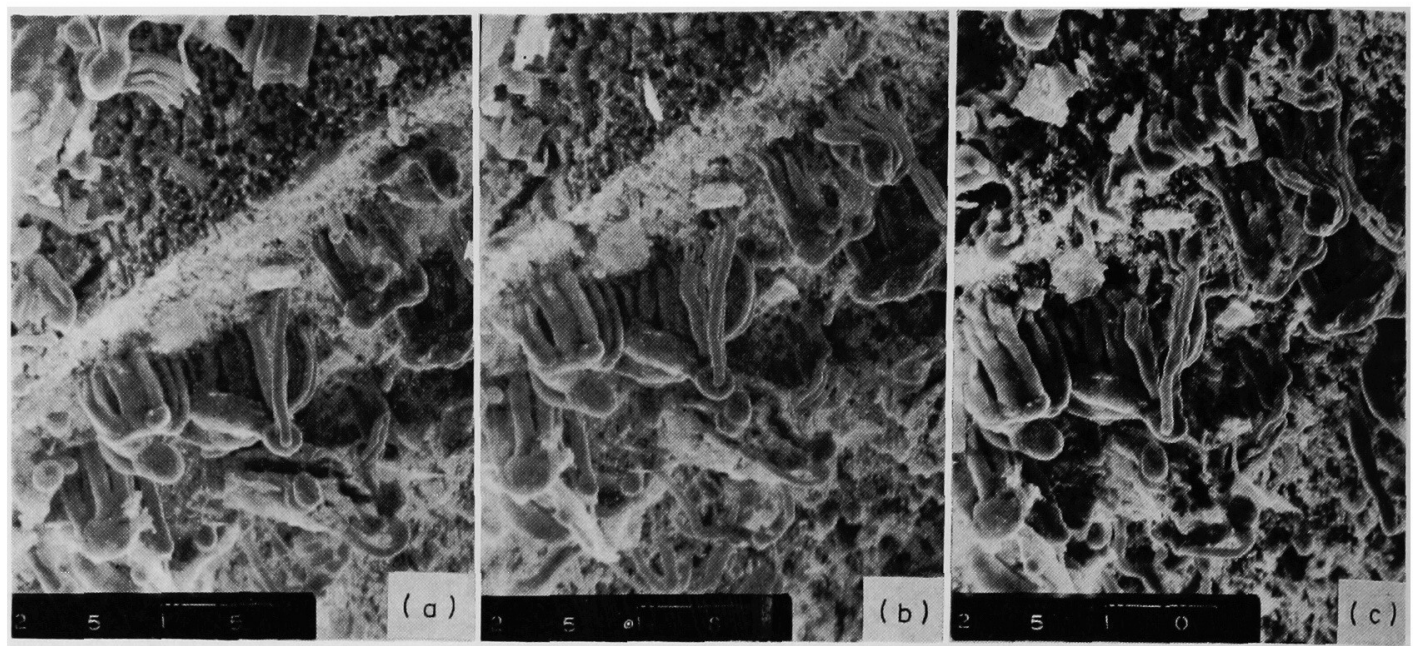

Photo. 4. Continuous observation of fibrous iron growth during the reduction of $\mathrm{Fe}_{2} \mathrm{O}_{3}$ single crystal at $750^{\circ} \mathrm{C}$ in $\mathrm{CO}$ atmosphere.

(a) $30 \mathrm{~min}$ (b) $45 \mathrm{~min}$ (c) $90 \mathrm{~min}, \times 750$

料の表面を示したこの結果より $\mathrm{Fe}_{3} \mathrm{O}_{4}$ の (111) 面上 には繊維状金属鉄の成長はみられず，その断面方向比瀻 維状金属鉄の成長が顕著であることがわかる.

\section{$3 \cdot 2.4$ 鉄鉱石の $\mathrm{CO}$ 還元}

Photo. $3(0)$ に茂山磁鉄鉱を $\mathrm{COO}$ 気流中で Fe ま で還元した場合の裴面を示した。これからわかるように ステップの現打れる面上に㵶維状金属鉄がみられる.

板状に発達したブラジル 赤鉄鉱をP Photo. $3(\mathrm{p})$ に 示した.この赤鉄鉱粒子の平坦な面は (0001) 面と思わ れる、この粒子を $\mathrm{CO}$ 気流中で $\mathrm{Fe}$ まで還元した場合 の表面を Photo. 3 (q) に示すが，この場合も (0001) 面上には瀻維状金属鉄はみられず，その側面上に瀻維状 金属鉄の成長が起きている.

Photo. $3(\mathrm{r})$ にスワジーランド赤鉄鉱を $\mathrm{CO}$ 気流 中で Fe まで還元した場合の表面を示した。これからわ かるようにスワジーランド赤鉄钩のように結晶性がよく なく，不規則な粒界を有する酸化鉄を還元しても瀻維状 金属鉄の成長はみられない。

\section{$3 \cdot 2.5$ 繊維状金属鉄の成長過程}

Photo. 4 (a), (b), (c) に板状 $\mathrm{Fe}_{2} \mathrm{O}_{3}$ 単結晶を $\mathrm{CO}$ 気流中で $30 \mathrm{~min}, 45(30+15) \mathrm{mm}, 90(30+15+45) \mathrm{min}$ 還元した場合の，繊維状金属鉄の成長過程を同一箇所で 観察した結果を示した。これより繊維状金属鉄は還元時 間とともに，それの根本より成長することが明らかであ る.

\section{4. 考察}

以上の実験結果より $\mathrm{Fe}_{2} \mathrm{O}_{3} \rightarrow \mathrm{Fe}_{3} \mathrm{O}_{4} \rightarrow \mathrm{FeO}$ と還元が進 行するにしたがい, $\mathrm{Fe}_{2} \mathrm{O}_{3}$ の (0001) 面および $\mathrm{Fe}_{3} \mathrm{O}_{4}$ の (111) 面に平行なステップが見られることがわかつた. このステッブは规則的に現われ，その間隔は $1 \sim 2 \mu て ゙$ ある、 BLEIFUS22) が述べているように，このステップは 還元が進行するにともない，結晶内の酸素打よび鉄イ才 ンの再配列が起きるときの応力のだ生ずるものと考克 られている.

X線回折の結果から $\mathrm{Fe}_{2} \mathrm{O}_{3}$ の (0001) 面および $\mathrm{Fe}_{3} \mathrm{O}_{4}$ の（111）面は還元反応の過程で極めて安定であること がわかる．これは酸素のほぼ最密パッキングの層が結晶 中に安定して存在することを示している.このため, $\mathrm{Fe}_{2} \mathrm{O}_{3}$ の (0001) 面, $\mathrm{Fe}_{3} \mathrm{O}_{4}$ の (111) 面㧍よび $\mathrm{FeO} の$ (111) 面が一致するのであるう.そしてそれらの面に平 行なステップが生じていることにより，還元過程におい て結晶は $\mathrm{Fe}_{2} \mathrm{O}_{3}$ の [0001], $\mathrm{Fe}_{3} \mathrm{O}_{4}$ の [111], $\mathrm{FeO}$ の [111] の軸方向方一致した薄い結晶片の積み重なりによ つてできていると考えられる.それぞれの結晶片は緩く 結合されており，また微細な隹裂の存在も予想できる. この結晶片間の粒界内は $\mathrm{Fe}^{++}$の拡散が極めて容易と考 えられる. また, 同様に $\mathrm{Fe}_{2} \mathrm{O}_{3}$ のもう一つのへき開面 (10ī1) に沿つた粒界も存在すると思われ，2つのへき

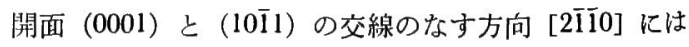
$\mathrm{FeO} \rightarrow \mathrm{Fe}$ の還元段階で $\mathrm{Fe}^{++}$の拡散が特に進みやすい 
と考えられる. 䋐維状金属鉄の成長過程を観察した結果 それは根本より成長することが明らかである。

瀻維状金属鉄の成長機棈について, 不破ら ${ }^{3)}$ や GRÄNSE) は次のように説明している.すなわち還元反忍で $\mathrm{FeO}$ の表面より酸素が除去されることによつて 過飽和 となつた $\mathrm{Fe}^{++}$とエレクトロンが，表面に生成した数少 ない核に集中的に拡散し鉄相となることにより緎維状金 属鉄が成長すると述べている．また小野田ら5)は瀻維状 金属鉄の成長現象について，これは表面反応速度と体拡 散速度との相対関係により決まるものと解している．著 者らむ同様な譏構により䋐維状金属鉄が成長すると考え るが，そこで注意したことは CO 還元の場合繊維状金 属鉄の成長は酸化鉄結唱の特定な面, すなわち $\mathrm{Fe}_{2} \mathrm{O}_{3}$ の (0001), $\mathrm{Fe}_{3} \mathrm{O}_{4}$ の(111)および $\mathrm{FeO}$ の(111)面上にはみ られず，それらの側面上にみられるということである.

吉越ら6)は, 人工 $\mathrm{FeO}$ (単結晶の集合体) を試料と し， $\mathrm{H}_{2}$ と CO 還元による鉄相の成長について検討し次 のことを明らかにしている. CO 還元では鉄核の発生す るまでの時間が $\mathrm{H}_{2}$ 還元より著しく長く，核はほとんど 試料のへりから発生する. 還元反応は鉄と $\mathrm{FeO}$ 相の界 面で進み，鉄相は多孔質である. 一方 $\mathrm{H}_{2}$ 還元では鉄核 は試料の表面にも発生し表面の鉄相の成長は速く，緻密 な鉄が $\mathrm{FeO}$ 表面を覆うと同時に $\mathrm{FeO}$ 内部に粒状に鉄 が形成される、この報告において $\mathbf{H}_{\mathbf{2}}$ 還元の場合には， 鉄相の成長速度は $\mathrm{FeO}$ 結晶の面指数に依存しないこと を確かめて実騟を行なつているが，CO 還元についてそ れを確かめていない。

$\mathrm{Fe}_{2} \mathrm{O}_{3}$ 単結晶を試料とし, $\mathrm{CO}-\mathrm{CO}_{2}$ および $\mathrm{H}_{2}-\mathrm{H}_{2} \mathrm{O}$ を用い $\mathrm{Fe}_{3} \mathrm{O}_{4}$ 安定域で還元したときの結晶面を観察し た報告7)がある、これによると $\mathrm{H}_{2}$ 還元では (0001) お よび $(10 \overline{1} 1)$ 面とも同様に気孔しかみられないが， CO 還元では (1011) 面上に $(0001)$ 面に平行な割れがみら れ，面指数により還元の進行が異なつている.このよう に $\mathrm{H}_{2}$ と $\mathrm{CO}$ による酸化鉄の還元性状の相異は現象論 的には明らかにされているが，還元ガスの特性による還 元機構の相異については十分に解明されていない.

著者らはこれまでの実験で明らかになつた現象および 上述した他の研究者の報告を参考にして，繊維状金属鉄 の成長機構について次のように考察を行なつた.

(1) $\mathrm{Fe}_{2} \mathrm{O}_{3}$ 板状単結晶の還元

$\mathrm{CO}$ 還元において鉄核は $\mathrm{Fe}_{2} \mathrm{O}_{3}$ の (0001) 面の侧面, すなわち還元された $\mathrm{FeO}$ の (111) 面の側面上に生成す る. $\mathrm{FeO}$ の (111) 面に平行に発達した粒界内の $\mathrm{Fe}^{++}$ の拡散速度は大きく, 核の周辺の $\mathrm{Fe}^{++}$浱度は低いため その流れは核に集中する。核において $\mathrm{Fe}^{++}+2 \mathrm{e} \rightarrow \mathrm{Fe} の$
反応により鉄相をなし，核の鉄相を押し上げるようにし て根本より繊維状金属が成長する. 表面反応速度は遅く 核はある大きさ（約 $1 \sim 3 \mu ）$ 以上にならないため，成 長した繊維状金属鉄の太さは注ぼ根本の太さと同様であ る. 核が $\mathrm{FeO} の$ (111) 面の側面上のステップに沿つて 細長く形成したときは，金属鉄は花弁状の突起となつて 成長する.

$\mathrm{H}_{2}$ 還元のときは鉄核は $\mathrm{FeO}$ 結晶の面指数に依存す ることなくして生成し，表面反応速度が大きいため鉄核 は成長し鉄相は結晶の全表面を覆う。この場合には特定 の核への $\mathrm{Fe}^{++}$の優先的な拡散は起らないため瀻維状 金属鉄の成長はみられない。

稀釈した $\mathrm{H}_{2}$ による還元の場合は， $\mathrm{CO}$ 䪪元の場合と 同様に鉄核は $\mathrm{FeO}$ の (111) 面の側面上に生成しやす い. $\mathrm{H}_{2}$ 浱度が低いため表面反応速度は遅く, それと比 較して体拡散速度が大きいため核に向かつて $\mathrm{Fe}^{++}$の拡 散が進み，繊維状金属鉄が成辰する。しかしCO 還元 の場合とは異なり，稀釈 $\mathrm{H}_{2}$ 還元の場合は緩やかではあ るが表面反応も同時に進行し，鉄核は $\mathrm{FeO}$ の表面上で 成長する.このため繊維状金属鉄は先端が細く根本が太 い形状を示す．核の成長がさらに進み核同志が接触し， やがて表面を鉄相が覆うようになると瀻維状金属鉄の成 長はとまるそのため CO 還元でみられるような細長 い纎維状金属鉄の成長はみられない.

\section{(2) $\mathrm{Fe}_{3} \mathrm{O}_{4}$ 八面体単結晶の逧元}

$\mathrm{Fe}_{3} \mathrm{O}_{4}$ の還元の場合も, $\mathrm{Fe}_{2} \mathrm{O}_{3}$ の場合とほぼ同様な機 構で還元が進行する. $\mathrm{Fe}_{3} \mathrm{O}_{4}$ の (111) 面, すなわち還 元された $\mathrm{FeO} の(111)$ 面に平行に発達した粒界内は $\mathrm{Fe}^{++}$の拡散が容易であり，また核生成は $\mathrm{FeO} の(111)$ 面の側面上に起きやすい. このため $\mathrm{FeO} の(111)$ 面上 には繊維状金属鉄はみられず，(111）面の側面上にのみ その成長がみられる。

\section{(3) 鉄鉱石 3 種類の還元}

スワジーランド赤鉄鉱は規則性のない結晶粒を有し， この鉱石を還元しても $\mathrm{Fe}^{++}$の拡散が容易な粒界が生 じ難いため繊維状金属鉄の成長はみられない。

ブラジル赤鉄鉣は $\mathrm{C}$ 面の発達した層状構造を有し，板 状単結晶を還元した場合と同様に繊維状金属鉄の成長が みられる。

茂山磁鉄鉱の還元の場合もステップの生成がみられ， その面上に繊維状金属鉄が成長する。

\section{5. 結言}

酸化鉄単結晶を試料に用い，還元過程における絬晶配 列の変化を観察するとともに，瀻維状金属鉄の成長機構 
について検討し次の結果を得た.

(1) 還元過程において $\mathrm{Fe}_{2} \mathrm{O}_{3}$ の (0001) 面は $\mathrm{Fe}_{3} \mathrm{O}_{4}$ の (111) 面に, さらに $\mathrm{FeO} の$ (111) 面にエピタキシ ュアル反応により変化する． $\mathrm{FeO}$ まで還元が進行する にしたがい, $\mathrm{FeO}$ の (111) 面に平行なステップが (111) 面の側面上に規則的に現れる.

（2） $\mathrm{FeO}$ まで還元された粒子は， $\mathrm{FeO} の[111]$ 軸 の方向が一致した薄い $(1 \sim 2 \mu)$ 結晶片の積み重なりに よつてできており，その間の粒界内は $\mathrm{Fe}^{++}$拡散が容易 と考えられている.

（3）さらに還元が進み $\mathrm{FeO}$ の (111) 面の側面上に 核が生成すると, 過飽和の $\mathrm{Fe}^{++}$は $\mathrm{FeO}$ の (111) 面 に平行に発達した粒界内を鉄核に出かつて搪散する。核 において $\mathrm{Fe}^{++}$はエレクトロンと結合して鉄相となり， 核を押し上げるようにして繊維状金属鉄の成長が進むる のと考えられる.

（4）繊維状金属鉄は $\mathrm{FeO} の$ (111) 面の側面上に 成長し，(111）面上にはみられない。この理由は鉄核は $\mathrm{FeO}$ の（111）面上に生成し難いためと, (111) 面上の 核にむかつて $\mathrm{Fe}^{2+}$ が容易に拡散できる粒界が存在しな いためと思われる.
（5）繊維状金属鉄が成長するためには，鉄核の生成 および成長速度と比較して大きな速度で $\mathrm{Fe}^{++}$の拡散が 可能な粒界の存在が必要と思われる.したがつて結晶性 のよい酸化鉄を還元した場合に繊維状金属鉄が生長しや すいものと考えられる.

おわりに本研究に関し有益な御教示を頂いた北海道大 学工学部金属工学科吉井周雄教授ならびに応用化学科松 下徹教授に深く感謝の意を表します。

\section{交献}

1) S. Sayama and $Y$. Ueda: Proceedings of the First International Conference on the Compaction and Consolidation of Particulate Matter (1972), p. 89

2 ) R. L. Bleifuss: Proceedings ICSTIS, Suppl. Trans. ISIJ, 11(1971), p. 52

3 ) $T$. Fuwa and $S$. Banya: Trans. ISIJ, 9(1969), p. 137

4) L. GRÄnSE: Proceedings ICSTIS, Suppl. Trans. ISIJ, 11(1971), p. 45

5 ) 小野田, 佐々木, 領, 德田: 選研量, 24(1968), p. 91

6 ) 吉越, 徳田, 大谷: 金属誌, 11(1972), p. 1093

7 ) 富士鉄中研: 学振 54 委, 76(1969) 